\title{
Determinants of Bank Business Risk According to Risk-Based Approach
}

\author{
K. Haryakusuma \\ Universitas Airlangga \\ Surabaya, Indonesia \\ haryakusuma.kurnia@gmail.com
}

\begin{abstract}
Banks have important role on the economy of Indonesia. With a fully regulated principle, Banking Sectors in Indonesia concern to keep in a good performance according to Bank Indonesia Regulation No. 13 / 1 / PBI / 2011 which emphasize on risk-based approach. Therefore, this paper aims to examine the factors affecting commercial banks business risk listed on Indonesia Stock Exchange. Those factors consist of risk profile (credit risk, liquidity risk, and interest rate risk), good corporate governance, earnings, and capital. The samples used in this research are 26 commercial banks listed on Indonesia Stock Exchange during research period since 2011 to 2013. This research uses multiple linear regression analysis. The result of the findings shows that credit risk has effect against business risk, while liquidity risk does not have effect against it. The rate of interest risk has effect against business risk. Good corporate governance does not have effect against business risk. Earnings have significant effect against business risk. Capital does not have effect against business risk. Hence, the implication of the research is that commercial banks business risk is affected by three factors of risk-based bank rating (credit risk, interest rate risk, and earnings).
\end{abstract}

\section{Keywords-credit risk; interest rate risk; earnings}

\section{INTRODUCTION}

\section{A). Background}

The role of banking sector is very substantial for the economy of a nation. Through the function of financial intermediation, bank has a special role as intermediary fund from surplus party (lenders) to deficit party (borrowers). The existence of bank helps the process of production, distribution, and consumption through mobilizing the fund from and to the society to improve the monetary transmission. This role will contribute to stronger financial system, so economic development will be achieved [1].

The application of bank-based financial system in Indonesia is due to the society that gets used to banking activity rather than market-based system [2]. Hence, bank has the important role to mobilize the fund, allocate capital, and provide risk management. Most companies in Indonesia depend on bank to finance the external process because Indonesia is using banking system [3]. The company debt will possibly make them facing financial distress. In other words, real factors are fragile against the performance of the banking industry.

The high dependence of Indonesia citizens towards banking services in Indonesia is reaching $77.9 \%$. Compared to the other financial institutions, rural banks is $1.3 \%$, Insurance Company is $10.8 \%$, Pension Fund is $2.8 \%$, Corporate Financing is $6.8 \%$ and the other non-bank institutions is $(0.9 \%)$ [4]. Based on the fact, people in Indonesia still prefer to banking sector rather than the other capital market activity. Accordingly, the banking industry is required having good corporate governance to keep the credibility that supports to economic stability.

In response to the trustworthiness from society in Indonesia, $80 \%-90 \%$ fund that bank has compiled are from third party fund. The source of bank funding is from third party fund obtained through banking products such as from saving deposit, demand deposit and time deposit. In 2013, the percentage amount of third party fund is $89.62 \%$, dominated by demand deposit and time deposit [6]. The higher reliance from banking customers on third party fund proportion would increase the risks for bank management to carry out the social fund. To keep the society trustworthiness, a prudent principle must be implemented in the banking industry because it relates to the business sustainability.

The banking industry in Indonesia has grown significantly, characterized by a number of banks and banking offices. The growing industry in banking sectors in Indonesia was an impact of Package of Bank Indonesia Deregulation on October 27, 1988 which is known as Pakto 88 [7]. The aims of the reforms were to inject a greater level of competition into banking sector and to increase credit availability throughout the country [8]. Pakto 88 had triggered the banking liberalization in Indonesia. Banking liberalization eased the restriction of bank establishment, consequently a year after this term applied, the number of banks and offices were growing significantly.

The high level of rapid competition in banking industry would lead the banks to take an excessive risk because of the difficulty to predict the phenomenon in a rapid competition [9].

Bank is a financial institution that manages money to be the main object of its operations. Because of that, bank has 
inherent risks systematically. There are various types of risks on bank exposed from its operations including primary risks such as liquidity risk, operational risk, credit risk, interest rate risk, solvency risk, market risk, business risk, default risk, strategic risk and compliance risk, but the influential risks on banking industry are operational risk that arise from the events beyond management control, liquidity risk which substantially it relates to the ability to resolve all of the bank's necessities, credit risk that occurs of credit distribution especially from non-performing loans, market risk and interest rate risk because those risks are having tight relationship and would make a contagion effect (occurrence of phenomenon that would impact the overall condition) if those primary risks are not managed well [9].

The impact of risks would decrease the bank's performance [10]. Hence, the bank should have reliable risk management to handle the impact of risks and the possibility of loss would be minimized and it will also enlarge the possibility to maximize the profits. Because bank warrants the fund from society, all of activity from financial services involving banking industry or non-bank industry have been supervised by Indonesian Financial Services Authority to create an organized, transparent, fair and accountable financial services.

Bank of International Settlement (BIS) has launched accords to be a guidance of bank's operation through the implementation of Basel I and Basel II (the rule of the Basel Committee on Banking Supervision in managing risk). Basel I rules are considered as less adequate in the development of the current banking risk management, eventually replaced by the rules of Basel II, which up until now is stipulated by Bank Indonesia in banking risk management benchmark [10].

Bank Indonesia as a regulatory institution of banking industry, prompted a basic framework for Indonesian Banking System through Indonesian Banking Architecture which function is to give direction, outline and structure of the banking industry for the next five to ten years. Indonesia Banking Architecture (API) is urgently needed to strengthen the fundamentals of banking industry after facing economic crisis in 1997 that inadequate infrastructure would impact the financial system instability.

In 2004, Bank Indonesia had launched API that linked to government under Presidential Instruction No. 5 of 2003, API has three pillars to be implemented in banking industry [10]. The global financial crisis occurrence was giving the new understanding about comprehensive risk management, the enhancement of risk management and good corporate governance purposed that commercial bank in Indonesia could identify the early problem and giving solution more quickly. Along with that condition, Bank Indonesia reevaluates the method of commercial bank performance assessment to be more comprehensive and reliable to manage the risk. Principally, the level of bank performance is determined by the management of bank. Therefore, bank management must do the self-assessment periodically toward the performance. On the other side, Bank Indonesia evaluates the level of bank performance and it will be supervised by OJK to maintain the financial stability [11].

Risk management on banking industry should be conducted. Uncertainty will result in adverse variation of probability or in losses [9]. There are several ways to deal with risks such as avoiding, controlling, transferring and accepting. Risks in banking industry are not only affecting the internal aspect of bank's management but also affecting the external aspect that contributes to the instability of financial system because of unsuccessful monetary transmission and intermediation function. In the end of 2008, global financial crisis that occurred in United States (subprime mortgage given to debtor bears bad financial portfolio and creditworthiness) slightly affect the financial condition in Indonesia because of the strong financial system at that time [12].

Since Bank Indonesia has stipulated new method of bank performance assessment, Bank performance assessed by risk-based analysis (RGEC). A bank performance is comprehensively evaluated through the aspect of Risk Profile, Good Corporate Governance, Earnings and Capital. This method is used to replace the former method of bank performance parameter, CAMELS rating, that evaluates bank's performance according to the Capital Adequacy, Asset Quality, Management, Earnings, Liquidity and Sensitivity to Market Risk. Generally, both approaches are having similarity principles, but in RGEC the parameter used is more complicated and it has comprehensive factors to be analyzed. Actually, CAMELS parameter is obtained from the key financial ratios from bank financial report. For example, Capital Adequacy Ratio is used to measure capital adequacy at bank, Non-Performing Loan is used to measure asset quality of bank that derives from credit granted, Good Corporate Governance is used to measure the management of bank, Loan to Deposit Ratio is used to measure Liquidity of bank from credit granted and third party fund, and Sensitivity is measured by interest rate risk ratio that indicates the market's condition from interest rate volatility.

In the aftermath of global financial crisis, Bank Indonesia through Banking Regulation No.13/1/PBI/ 2011 stipulates more complex assessment method for bank to assess the performance. Bank Indonesia obligates all of banks in Indonesia to use risk-based method that focus on risk profile which must be integrated into inherent bank risks, good corporate governance, earnings, and capital [13].

The general principles of new rating method are stipulated just because of several reasons, the assessment must be oriented on risk exposure, significances, and it must be executed systematically and comprehensively [14]. The first reason is the assessment of bank performance, basically taking from bank risks which influenced the overall of bank performance. By identifying both internal and external factors that could trigger risk exposures on bank operation, Bank expectedly could prevent and detect the root cause of problems and taking correction effectively and efficiently.

The second reason of assessment is considering the significances, means that Bank must concern on the significance of assessment factor from Risk Profile, GCG, 
- Interest rate risk

Earnings and Capital as well the indicator of each factor to concluded the finding of assessment and analyzed the result which provided by sufficient data and information.

The third reason of bank performance assessment, Bank must execute comprehensively and analyze systematically by considering the relation among the risks and assessment factor of bank. The analysis must be supported by primary facts and relevant ratio to show the trend and problems face by Bank.

There are many interactions between bank risk that come up from its business with a number of key determinants factors such as capital, operating efficiency, funding sources, securitization, corporate governance and diversification. The finding shows that four determinants of bank risk such as capital structure, asset structure, funding structure, income and managerial performance are having negative relationship toward systematic risk on European Banks. While, the research from Soedarmono \& Prasetyantoko [16] has a result that there is a distinction of bank risk implication to the aspect of capital, liquidity, and asset quality, found that loan to deposit ratio (LDR) and non-performing loan (NPL) has negative influence toward the business risk, while capital adequacy ratio (CAR) has positive influence towards bank business risk. Syafitri's [3] research shows that CAR, NPL, LDR, and SIZE has simultaneous positive relationship toward the business risk on commercial bank listed on Indonesia Stock Exchange during 2008 until 2011.

This research aims to know the effect from determinants of bank risks which is obtained from risk-based rating method components towards the business risk of commercial bank that listed on Indonesia Stock Exchange, in return to be beneficial information for investors over the stipulation of new method of bank performance assessment from Bank Indonesia Rules.

\section{B). Risk On Commercial Banks}

As a financial intermediation and fund distributor, bank has inherent risk, risk loss on bank not only affect the condition of bank itself, but also affecting the customers and overall economic condition. Subsequently, occur risk systemic that specifically the default risk of bank that straightforwardly cause instability of financial system. Bank is fragile to the systemic risk on banking industry. The systemic risk could not be prevented if the bank has risk loss.

Risk management on bank is expected to strengthen the management on decision making, of accurate risk calculation [3]. Through the Bank Indonesia Regulation No. 15/12/PBI/ 2013 about application of risk management for commercial bank, elaborates the risks exposure that must be overcome on business activities. The following are several risks that must be controlled by bank:

- Credit risk

Risk occurs from the default debtor or the other parties to pay the obligation to bank.

- Market risk

Risk from the market condition include of changing of option price. Market Risk consist of several risks which are:
Risk from the changing of one of the financial instruments which come from trading book and banking book caused by interest rate volatility. Risk on the banking book involving repricing risk and yielding curve risk, basis risk and optionality risk.

- Exchange rate risk

Risk from the changing of trading book position and banking book position that caused by foreign exchange and gold.

- Commodity risk

Risk from the changing of trading book position and banking book position that caused by the changing of commodity price.

- Equity risk

Risk from the changing of trading book position of the stock price changing.

- $\quad$ Liquidity risk

Occur from insolvency of bank to fulfill the obligation from funding source such as from liquid asset or collateral and administrative claims.

- Operational risk

Risk from unavailability of the management or operation process because of human error, system or externalities.

- Legal risk

Risk related to the rules and weakness to follow the law and legal terms such as contract.

- $\quad$ Strategic risk

Risk arises from the stipulation of ineffective strategy and inappropriate with the vision and mission of bank.

Bank Indonesia stated that there are four risks on commercial bank that must be controlled: credit risk, liquidity risk, market risk and operational risk. There are four risks approached in risk management consisting of credit risk, liquidity risk, market risk and operational risk [3]. There are three main categories of risks that have a mention in the capital accord namely: Credit Risk, Market Risk and Operational Risk [17]. Credit risk, a major source of loss, is the risk that customers fail to comply with their obligations to service debt. Major credit risk components are exposure, likelihood of default, or deterioration of credit standing, and the recoveries under default. Modeling default probability directly with credit risk models remains to be a major challenge, and it is not addressed until recent years. Market Risk may be defined as the possibility of loss to bank caused by the changes in the market variables. Market risk management provides a comprehensive and dynamic framework.

There are two ways of managing risk on commercial bank: controlling and minimalizing the exposures. The controllable risks categorized as credit risk, liquidity risk, and market risk [18]. While, the minimalized risk is operational risk which is exposed by the operational of commercial bank, related to compliance activities.

Bank Indonesia through the rules no 13/1/PBI/ 2011 stipulates the eight risks that occur in banking industries such as credit risk, market risk, interest risk, liquidity risk, 
is a ratio between interest income minus the interest expense divided by average interest-earning assets [25]. [13].

Risk variables used in this research are based on commercial bank business risks upon the financial ratio that measured the risks on bank. The data variable taken are factors that influence the business risk on bank Risk Profile.

\section{C) Business risk}

Business risk on bank has a meaning of uncertainty that bank could not generate income against the investment upon the cost and income of its business activities [3]. Meanwhile, business risk as potential variability in earnings before interest and taxes are generated from business environment of commercial bank [19]. Business risk is measured by SDROA (Standard Deviation of Return on Asset) and being the dependent variable. A common risk measurement is using standard deviation [20] [21]. SDROA is used to measure total volatility of profits reflected by ROA. SDROA is a comprehensive measurement to reflect the credit risk, interest risk, operational risk and the other risk on return of banks [22].

\section{D). Risk Profile}

\section{1) Credit Risk}

Credit Risk exposed a failure from borrowers to pay off all the obligations to bank. This research uses NPL ratio to measure the credit risk from the commercial banks.

\section{2) Liquidity risk}

Second risk profile, liquidity risk which defined as a bank's ability to meet its obligation as they come due, including deposit withdrawals and loan demand and administrative claims [22]. Liquidity is the ability of banks to meet the possibility of withdrawal of deposits or deposits by depositors or peer funds or meet the needs of the community in the form of credit [23].

Liquidity risk could be indicated from two aspects in commercial bank, the first is from on-balance sheet including the deposit of third party fund,deposit withdrawal and from off-balance sheet aspect including of commitment and contingency which reflecting the bank ability to cover commitment (The contract or notional amounts of those instruments reflect the extent of involvement the Bank has in particular classes of financial instruments), while contingency is a condition that is still overwhelmed by the uncertainty regarding the possibility of obtaining a gain or loss by a company [24]. By adding the committed liabilities and contingent liabilities, it would be known how much liabilities of commercial bank from off-balance sheet aspect.

\section{C) Interest rate risk}

In the Asset Liability Management, the important term is the interest rate risk because it can adversely affect bank cash flows (reinvestment risk) and equity values (price risk). The variability of NIM is important to evaluate interest risk. NIM

\section{D) Corporate Governance}

Good Corporate Governance has a broad definitions. According to Cadburry Committee, Good Corporate Governance is a principle that directed and controlled companies to achieve goals by balancing strength and authority to give contribution to shareholders [26]. Meanwhile, Organization Economic Cooperation and Development defining GCG as principles used by company to be transparent, accountable, independent, and fairness to maximize shareholders' value.

Experiencing from global financial crisis, Bank Indonesia encourage all banks in Indonesia to enhance the effectivity of risk management and Good Corporate Governance, along with the accomplishment of new method of bank performance assessment by using risk-based bank rating so that this purposes to increase performance, protect stakeholders and enhance the compliance against the rules and ethics make GCG to become a second component of evaluation for bank to make self-assessment. Upon the rules No. 15/15/PBI/2013, Banks must apply five basic principles as follows [27]:

- Transparency, which is about disclosing information relevant to the decision making process.

- Accountability, which is a clear function and banks need to be accountable in order to get effectiveness management.

- Responsibility, the compliance of bank to follow the rules.

- Independency, a bank manages the business professionally without any pressure or influence from any parties.

- Fairness, which means that bank need to fulfill the rights of stakeholders with equality and fairness according to the rules.

To ensure the application of five principles of GCG, Bank must do self-assessment at least encompasses 11 factors of GCG implementation as stated below:

- Implementation of duties and responsibilities of the Board of Commissioners.

- Implementation of duties and responsibilities of Board of Directors

- Implementation of the Board of Commissioners' duties and responsibilities

- Completeness and Implementation of Committees' Duties

- Implementation of Compliance Function

- Implementation of Internal Audit Function

- Implementation of External Audit Function

- Application of Risk Management including Internal Control System

- Provision of Funds to Related Party and Large Exposure.

- Bank’s Strategic Plan. 
the strength of the relationship between two or more variables, it also indicates the direction of the relationship between the dependent variable and independent variables [33].

Multiple linear regression model (multiple linear regression method) is used to determine whether there is a significant effect on the dependent variable or more than one independent variable.

The model of this research arranged in one linear equation as follows:

Model:

$$
\mathrm{BR}_{\mathrm{C}}=\mathrm{a}+\mathrm{b}_{1} \mathrm{CR}_{\mathrm{t}}+\mathrm{b}_{2} \mathrm{LR}_{\mathrm{t}}+\mathrm{b}_{\mathrm{a}} \mathrm{IRR}_{\mathrm{t}}+\mathrm{b}_{4} \mathrm{GCG}_{\mathrm{t}}+\mathrm{b}_{5} \mathrm{E}_{\mathrm{t}}+
$$

$$
\mathrm{b}_{6} \mathrm{C}_{\mathrm{t}}+\mathrm{e}_{\mathrm{i}}
$$

\section{F). Capital}

Capital is one of the factors that are important for banks to develop its business and to accommodate losses [29]. Capital for banks as the company in general in addition to functioning as the main source of financing for activities also play an operational role, as a buffer against losses. Capital owned by a bank basically should be sufficient to cover the entire risk business faced by banks. The capital adequacy ratio is the ratio of the aims to ensure that banks can absorb losses of the activities done [30]. Under the agreement Basel I, the ratio of the minimum capital for the banking industry is implemented by $8 \%$ [31]. Bank capital is fairly or very important because a lot of bank capital is intended to facilitate the operations of a bank [32].

According to the regulations of Bank Indonesia No. 15/12/PBI/2013, each bank shall meet the capital adequacy of $8 \%$ [27]. The level of capital adequacy of the banking is represented by the ratio of capital adequacy ratio (CAR). CAR shows how much of the bank's total assets that involve risks, which financed of capital itself. High and adequate capital adequacy will increase the volume of bank credit [3].

\section{METHOD}

\section{A) Data and Sample}

This research uses purposive sampling method with a certain criteria: commercial banks that applied the risk- based method since 2011 based on the provision of Bank Indonesia No. 13/1/PBI/2011 and reported to the Bank Indonesia and Indonesia Stock Exchange. Based on the criteria, the research sample consists of 26 banks [13].

\section{B) Analytical Data}

The approach used in this study is a quantitative approach, which analyzed the measurement of economic phenomenon which is a combination of economic theory (financial statement information), mathematical and statistical models that are classified in a particular category by using the specific tables in order to simplify the analysis using EViews 8.00. Meanwhile, the analytical techniques used is multiple linear regression analysis techniques. So, the relationship between a dependent variable with more than one independent variable can be seen. In regression analysis, in addition to measuring
Where:

$\mathrm{BRc}=$ Business risk that measured by Standard Deviation ROA

a $=$ Constanta

b1- b6 = Coefficient Regression

CRt $\quad$ Credit Risk

LRt = Liquidity Risk

GCGt = Good Corporate Governance

Et = Earning

$\mathrm{Ct} \quad$ = Capital

$\mathrm{Ei} \quad=$ Residual Error

TABLE 1. MULTIPLE REGRESSION ANALYSIS

\begin{tabular}{|l|l|l|l|l|}
\hline Variable & Coefficient & St. Error & t-Test & Result \\
\hline Business risk & .1236777 & .555836 & .8251 & \\
\hline Credit risk & .278481 & .079549 & 3.5007 & Significant \\
\hline Liquidity risk & .197772 & .780208 & .8013 & Insignificant \\
\hline Int. rate risk & .72366 & .153530 & 4.7134 & Significant \\
\hline GCG & -.0578 & .135130 & .7848 & Insignificant \\
\hline Earnings & 11.31716 & 3.658546 & .0037 & Significant \\
\hline Capital & -.04174 & .017942 & .8193 & Insignificant \\
\hline R-Squared & .880182 & \\
\hline Adjusted R-Square & .839192 & \\
\hline F-statistics & 21.47300 \\
\hline Durbin Watson & 1.954 \\
\hline Schwarz Criterion & 1.83 \\
\hline
\end{tabular}

\section{DISCUSSION}

It can be explained that the Bank has a function as a financial intermediary, so that the characteristics of the bank's business is to bring the surplus spending units to deficit spending units. Funds raised from the public that the excess will be disbursing funds in the form of a credit to the cashstrapped. The risk of the bank's business is when the lender can not repay its obligations on time. This possibility is referred to as a credit risk. The greater the credit risk, the greater the risk of the bank's business risk.

Based on the summary of the multiple linear analysis results in Table 1, it appears that liquidity risk does not have effect on 
total asset is, the greater the business risk is. The greater overhead expense in the current year also affect to the greater of business risk.

Based on the summary of the multiple linear analysis result shown in Table 1, it appears that capital does not have any effect but on the business risk. Bank capital has function to minimize the bank business risk. A greater sufficient capital could prevent bank from risk loss effect. Previous research from Bautista, Rous \& Tarazi [37] shown that Capital Adequacy is significantly negative toward business risk. According to Bank Indonesia Rule No 15/12/PBI/2013, the minimum capital required for all banks is $8 \%$. Hence, capital does not affect the business risk [27].

According to Bank Indonesia, essentially the risk based bank rating approach is consist of Risk Profile, Good Corporate Governance, Earning and Capital. Risk Profile consists of inherent risk that encompasses of eight risks (credit risk, operational risk, market risk, interest rate risk, liquidity risk, compliance risk, reputation risk and legal risk). This research only observes the components of risk-based approach from Risk Profile on credit risk, liquidity risk and interest rate risk. Therefore, the next researchers are expected to observe bank performance according to risk-based approach with full aspects of risk profile.

\section{CONCLUSIONS} interest rate risk causes the variability of interest net income. Therefore, the greater the interest rate risk is, the greater of business risk is.

Previous research, Stiroh [35], Syafitri [3] and Prasetyo [38] shown that NIM has positive effect on business risk. Based on the summary of the multiple linear regression analysis result shown in Table 1, it appears that corporate governance does not have effect on business risk. The result could be explained that banking services are doing the business according to the financial regulation. Good Corporate Governance has important role to maintain the performance of banks to prevent any damage of contagion effect. Therefore, well GCG implementation on bank does not affect the business risk significantly. This finding fits with the finding from Syam \& Najdah [36] who stated that good corporate governance in Sharia Bank does not affect the risk of return on stocks. Based on the summary of the multiple linear regression analysis results shown in Table 1, it appears that earnings has significant effect on the business risk. Therefore, the results is consistent with the hypotheses.

This would be elaborated that Earnings shows the ability of the company to generate profits. In this research, earnings is measured by overhead expense to total asset to know the bank efficiency to overcome operational expense [28].

This research uses an indicator from overhead expense to measure earnings. The greater the overhead expense is, the greater the fixed cost for bank is. This term would require bank to obtain sufficient income to cover that cost [28]. By this condition, Bank will suffer of business risk effect. Hence, the greater the earning measured by overhead expense toward
Based on the analysis and discussion of the findings and research, it can be concluded that:

- Credit Risk has significant effect against business risk. It means that, a failure of a debtor to pay off the obligation to bank would affect the operation of bank to suffers business risk.

- Liquidity Risk does not have effect against the business risk, it means that bank has more liquidity to cover its obligation either it derives from withdrawal deposit, loan demand, or administrative transaction account.

- Interest rate risk has significant effect on business risk. It means that in the bank operation to distribute credit, the volatility of interest rate is very important to generate the bank income.

- Good Corporate Governance does not have effect but on business risk. It means that, a good implementation of Good Corporate Governance on commercial bank stipulated by Bank Indonesia Regulation No. 15/15/DPNP/2013 would decrease the risk of bank businesses.

- Earning has significant effect on business risk. It means that, by using overhead expense to total assets as a parameter to calculate the earning of bank from the aspect of efficiency. Obtain the relationship that, a greater overhead expense also has a greater effect to the business risk. It indicates that bank faces inefficiency in its operation. 
[19] Keown, A. 2004. Dasar- dasar manajemen keuangan. Jakarta: Salemba Empat Publisher.

- Capital does not have effect against business risk, it means that bank has sufficient amount of capital to cover obligation and according to Bank Indonesia Regulation No. 15/12/2013 that Commercial bank has to fulfill the minimum of capital adequacy of $8 \%$.

Bank failures have contagion effect, therefore improving supervision from Financial Services Authority that Credit risk, interest rate risk, and earning are having significant effect on business risk of commercial banks are needed. Thereby, bank management also needs to improve the accuracy of credit distribution to minimize credit risk. Furthermore, it is necessary to raise capital because it can minimize the risk of business banks.

\section{REFERENCES}

[1] Koch, T.W., Edwards, V., MacDonald, S. \& Duran, R.E. 2014. Bank Management: A Decision-Making Perspective. Singapore: Cengage Learning.

[2] Schmukler, S. \& Vesperoni, E., 2001. Firms' financing choices in bankbased and market-based economies. Financial structure and economic growth: A cross-country comparison of banks, markets, and development, p.347.

[3] Syafitri, E. D. 2011. Pengaruh CAR, NPL, LDR, NIM dan SIZE terhadap risiko bisnis bank: Studi komparatif bank umum go publik dan bank umum non go publik di indonesia periode 2004-2008. Minor Thesis of Undergraduate Management Study. Semarang: University of Diponegoro.

[4] Bank Indonesia. 2014. Indonesia Banking Statistics-March 2014

[5] Bank Indonesia. 2013d. Indonesia Banking Architecture. 2013.

[6] Bank Indonesia. 1988. Deregulasi Perbankan 1988: Paket Kebijaksanaan Oktober 1988 (PAKTO 88).

[7] Bennett, M. 1999. Banking deregulation in Indonesia: An Updated Perspective in Light of the Asian Crisis. Journal of International Economic Law 20(1). University of Pennsylvania: 10-15.

[8] Kuncoro \& Suhardjono. 2002. Manajemen Perbankan (Teori dan Aplikasi), Edisi Pertama. Yogyakarta: BPFF Publisher.

[9] Bessis, J. 2002. Risk management in banking. Second Edition. New York: Wiley Press.

[10] Bank Indonesia. 2013a. Banking and financial stability reviews. 2013. No 21. September 2013.

[11] Rivai, V., Basir, S. \& Sudarto, S. 2013. Commercial bank management: Manajemen perbankan dari teori ke praktik. Bogor: Raja Grafindo.

[12] Wiyanti, S. 2013. Perbedaan Krisis Ekonomi 1998, 2008 dan 2013 versi Bank Indonesia.

[13] Bank Indonesia. 2011a. Bank Indonesia Regulation No. 13/1/PBI/2011 about Commercial Bank Assessment Performance.

[14] Hermana, B. 2012. Penilaian kesehatan bank (RGEC): Risk Profile. Jakarta: Graha Pena Gunadarma.

[15] Altunbas, Y. \& Manganelli, S. 2011. Bank risk during the financial crisis (Do business models matter?). Working Paper No 1394. European Central Bank.

[16] Soedarmono, W. \& Prasetyantoko. 2008. Risk based capital regulation and indonesian banking fragility: Impact of competition and asymetric credit supply. Jakarta: Atma Jaya Research Library.

[17] Aggarwal, R. \& Arora, D. 2009. Banking risk management in India and RBI supervision.

[18] Hidayati, E.E., 2010. Analisis pengaruh DER, DPR, ROE dan SIZE terhadap PBV perusahaan manufaktur yang listing di BEI periode 20052007 (Doctoral Dissertation, Universitas Diponegoro).
[20] Sunaryo, T. 2007. Manajemen risiko finansial. Jakarta: Salemba Empat Publisher.

[21] Godlewski, C. J. 2004. Capital regulation and credit risk taking; empirical evidence from banks in emerging market economics. Working Paper, Robert Schuman University, France.

[22] Naimy, V. Y. 2005. Overall Lebanese banks' performance: A risk-return framework. International Business and Economics Research Journal 4(1)

[23] Taswan. 2010. Manajemen Perbankan Edisi 2: Konsep, Teknik, dan Aplikasi. Yogyakarta: UPP STIM YKPN Publisher

[24] Bank Indonesia. 2013b. Letter No 15/15/DPNP in 2013 in term of Good Corporate Governance Implementation on Commercial Bank

[25] Sinkey, J. F.Jr. 2002. Commercial bank financial management 6th Edition. New Jersey: Pearson.

[26] Daniri, A. 2014. Lead by GCG. Jakarta: Gagas Media.

[27] Bank Indonesia. 2013e. Rules No. 15/12/PBI/ 2013 in term of Minimum Capital Requirement for Commercial Bank

[28] Kunt, A.D., Laeven. \& Levine. 2003. The Impact of Bank Regulations, Concentration, and Institutions on Bank Margins. World Bank Policy Research Working Paper.

[29] Taswan. 2006. Manajemen Perbankan Edisi I. Yogyakarta: UPP STIM YKPN Publisher.

[30] Bank Indonesia. 2013c. Bank Indonesia Regulation No.15 / 12 / PBI / 2013 dated December 12, 2013 on Capital Adequacy of Commercial Banks.

[31] Idroes, F.N. 2008. Manajemen risiko perbankan : pemahaman pendekatan 3 pilar kesepakatan BASEL II terkait aplikasi regulasi dan pelaksanaannya di Indonesia. Jakarta: Grafindo Perkasa Publisher.

[32] Siamat, D. 2005. Manajemen lembaga keuangan, kebijakan moneter dan perbankan. Jakarta: Faculy of Economics. Universitas Indonesia.

[33] Ghozali, I. \& Ratmono, D. 2013. Multivariate analysis and econometrics: theory, konsep,and application using eviews 8.00 . Semarang: Faculty of Economics and Business Press, University of Diponegoro

[34] Santos, J.A. \& Rumble, A.S., 2006. The American keiretsu an universal banks: Investing, voting and sitting on nonfinancials' corporate boards. Journal of Financial Economics, 80(2), pp.419-454.

[35] Stiroh, K. J. \& Adrienne, R. 2005. The dark side of diversification: the case of us financial holding companies. Journal of Banking and Finance 30. New York: Federal Reserve Bank of New York.

[36] Syam, D. \& Najda, T. 2012. Analisis kualitas penerapan good corporate governance pada bank umum syariah di Indonesia serta pengaruhnya terhadap tingkat pengembalian dan risiko pembiayaan. Research of Accounting Department. Malang: University of Muhammadiyah.

[37] Bautista, C., Rous, P. and Tarazi, A., 2008. The determinants of domestic and cross border bank contagion risk in Southeast Asia. Revue économique, 59(6), pp.1215-1242

[38] Prasetyo, M.I. 2013. Pengaruh kecukupan modal, kredit bermasalah, likuiditas, dan marjin bunga bersih terhadap risiko bisnis: studi pada bank umum swasta nasional devisa. Thesis of post graduate. Malang: University of Brawijaya 